\title{
Penambahan Bulking Agent untuk Meningkatkan Kualitas Kompos Sampah Sayur dengan Variasi Metode Pengomposan
}

\author{
Moh. Rohim, Arseto Y. Bagastyo \\ Jurusan Teknik Lingkungan, Fakultas Teknik Sipil Dan Perencanaan, Institut Teknologi Sepuluh Nopember (ITS) \\ Jl. Arief Rahman Hakim, Surabaya 60111 Indonesia \\ e-mail: bagastyo@enviro.its.ac.id
}

\begin{abstract}
Abstrak - Bahan utama pengomposan dalam penelitian ini adalah sayur dan sabut kelapa sebagai bulking agent. Kedua bahan tersebut digunakan karena ketersediannya yang melimpah di lokasi penelitian yaitu Pasar Puspa Agro, Sidoarjo. Variabel yang digunakan dalam penelitian ini adalah penambahan bulking agent dan metode pengomposan. Penambahan bulking agent yang digunakan yakni $40 \%, 50 \%$ dan $60 \%$ yang mana persentase tersebut diperoleh dari hasil perhitungan rasio $\mathrm{C} / \mathrm{N}$ campuran dari kedua bahan yang masuk rentang 25-40. Sedangkan metode pengomposan yang dipakai adalah metode 1 (tidak dicacah, dilapis), metode 2 (dicacah, dicampur) dan metode 3 (dicacah, dilapis). Dimensi pengomposan yaitu $0,5 \times 0,5 \times 1$ m dan pembalikan untuk metode 1 dan 3 yakni 3 hari sekali selama 2 minggu pertama, seminggu sekali sampai minggu keenam dan 2 minggu sekali sampai kompos matang. Sedangkan pada metode 2, pembalikan dilakukan 3 hari sekali sampai kompos matang. Parameter kualitas kompos yang digunakan mengacu pada SNI 197030-2004 meliputi suhu, pH, kadar air, kadar C-organik, $\mathbf{N}$ total dan rasio $\mathbf{C} / \mathbf{N}$. Hasil dari penelitian ini adalah jika ditinjau dari penambahan bulking agent kualitas kompos yang paling baik yaitu dengan penambahan $60 \%$. Apabila ditinjau dari metode pengomposan, kualitas kompos yang paling baik yaitu menggunakan metode 3 (dicacah, dilapis).
\end{abstract}

Kata Kunci-bulking agent, kompos, rasio C/N, sampah sayur, sistem windrow

\section{PENDAHULUAN}

$\mathrm{S}_{\mathrm{a}}^{\mathrm{a} a \mathrm{a}}$ lah satu sumber timbulan sampah kota yang cukup tinggi adalah pasar yaitu sebesar 7\% [1]. Hal ini karena tidak semua bahan di pasar terutama sayuran siap untuk dijual melainkan harus dipilih dan dibersihkan terlebih dahulu. Pengolahan sampah pasar dapat dilakukan dengan cara pengomposan. Pengomposan cocok diterapkan karena komposisi sampah pasar ialah jenis organik berupa sisa sayuran dan makanan yang mencapai $95 \%$ [2]. Prinsip pengomposan yaitu penguraian bahan organik (biodegradable) melalui proses biologis dengan bantuan organisme pengurai. Dalam prosesnya, mikroorganisme pengurai mengambil sumber makanan dari sampah atau bahan organik biodegradable dan menghasilkansisa metabolisme berupa $\mathrm{CO}_{2}$, uap air dan panas [3].

Pasar Induk Puspa Agro telah menerapkan sistem pengomposan dalam mengolah sampah pasarnya. Akan tetapi, berdasarkan analisis laboratorium pada Januari tahun 2015 kompos masih bermutu kurang baik karena rasio $\mathrm{C} / \mathrm{N}$ dalam kompos berada di bawah SNI spesifikasi kompos yaitu 7,53. Berdasarkan SNI 19-7030-2004 tentang Spesifikasi Kompos dari Sampah Organik dan Domestik, standar kualitas kompos untuk rasio $\mathrm{C} / \mathrm{N}$ adalah 10-20, unsur karbon 9,8-32 \% dan nitrogen minimum $0,4 \%$.

Dalam meningkatkan kualitas kompos maka diperlukan bahan tambahan dalam pengomposan. Dalam penelitian ini bahan yang ditambahkan adalah sabut kelapa. Sabut kelapa dipilih karena ketersediannya di Pasar Puspa Agro sangat melimpah. Selain itu sabut kelapa memiliki rasio $\mathrm{C} / \mathrm{N}$ yang cukup tinggi yaitu 91 (Hasil analisis Laboratorium Kualitas Lingkungan, 2016). Sabut kelapa juga berperan sebagai bulking agent dalam proses pengomposan karena sifatnya yang porous sehingga aerasi dalam tumpukan dapat tetap berjalan [4]. Kompos yang bermutu baik akan dapat memperbaiki struktur tanah dan meningkatkan pertumbuhan tanaman [5].

Tujuan dari penelitian ini yaitu untuk menganalisis kualitas kompos yang dihasilkan ditinjau dari variasi penambahan bulking agent dan variasi metode pengomposan. Dari hasil peneltian yang didapatkan dapat menjadi acuan dalam pengomposan sampah sayur pada umumnya terutama pada TPST Pasar Puspa Agro, Sidoarjo.

\section{METODOLOGI PENELITIAN}

\section{A. Kerangka Penelitian}

Penelitian ini berawal dari adanya permasalahan dari kualitas kompos yang dihasilkan di TPST Pasar Puspa Agro Sidoarjo yang berada di bawah SNI. Penelitian ini dilakukan dalam skala pilot bertempat di TPST Pasar Puspa Agro, sementara untuk uji parameter $\mathrm{C}$ dan $\mathrm{N}$ dilakukan di laboratorium Teknik Lingkungan FTSP ITS, Surabaya. Penelitian pendahuluan dilakukan untuk mengetahui karakteristik dari masing-masing bahan pengomposan. Pelaksanaan penelitian ini membutuhkan waktu 2 bulan waktu pengomposan. Metode yang digunakan ada 3 yaitu metode 1 (tidak dicacah, dilapis), metode 2 (dicacah, dicampur) dan metode 3 (dicacah, dilapis). Jumlah tumpukan untuk masing- 
masing metode adalah 3 tumpukan sesuai dengan variasi penambahan bulking agent $(40 \%, 50 \%, 60 \%)$. Ketiga tumpukan diduplo sehingga masing-masing metode terdapat 6 tumpukan, jadi total terdapat 18 tumpukan ditambah 2 tummpukan kontrol. Pengumpulan data meliputi kadar air, $\mathrm{pH}$, suhu, \%C-organik, \%N total dan rasio $\mathrm{C} / \mathrm{N}$. Selanjutnya data dianalisis dengan uji anova menggunakan software SPSS untuk mengetahui perbedaan rata-rata antar variasi dalam penelitian ini.

\section{B. Penelitian Pendahuluan}

Penelitian pendahuluan dilaksanakan di laboratorium Teknik Lingkungan FTSP ITS yaitu melalui uji karakteristik bahan pengomposan. Parameter yang diuji terhadap bahan pengomposan yaitu kadar air, $\mathrm{pH}, \% \mathrm{C}$-organik dan $\% \mathrm{~N}$ total. Hasil uji karakteristik ini menjadi pertimbangan untuk penambahan bulking agent yang perlu ditambahkan dalam pengomposan sampah sayur. Dari hasil penelitian penelitian didapatkan data seperti pada Tabel 1 berikut;

Table 1.

Hasil Uji Karakteristik Bahan Pengomposan

\begin{tabular}{ccccc}
\hline \hline Bahan & Kadar air (\%) & $\mathrm{pH}$ & \%C- organik & \%N total \\
\hline $\begin{array}{r}\text { Sayur } \\
\text { Sabut } \\
\text { kelapa }\end{array}$ & 93,00 & 3,25 & 34,50 & 2,52 \\
\hline \hline
\end{tabular}

\section{Tahapan Pembuatan Kompos}

Tahapan pembuatan kompos dalam penelitian ini merupakan langkah-langkah yang dilakukan dalam pengomposan mulai dari pembuatan cetakan hingga pemanenan kompos

1) Pembuatan cetakan

Cetakan dibuat untuk pengomposan metode 2. Bahan dari kawat berlubang (lubang berbentuk kotak, dimensi $0,5 \mathrm{~cm}$ ). Dimensi untuk masing-masing cetakan yaitu $0,5 \times 0,5 \times 1 \mathrm{~m}$. Pada sisi sudut dari cetakan kompos ini dilapisi dengan bambu untuk memperkuat cetakan.

2) Pemilahan sampah

Pemilahan sampah dilakukan untuk memisahkan bahan yang akan dikomposkan dengan bahan yang sulit untuk diuraikan misalnya plastik, karet dan kayu. Sampah yang digunakan sebagai bahan kompos hanyalah sampah sayur dan sabut kelapa saja.

3) Pencacahan bahan kompos

Pencacahan dilakukan pada tumpukan metode 2 dan 3. Sampah dicacah dengan mesin pencacah hingga berukuran $1-5 \mathrm{~cm}$.

4) Penumpukan bahan kompos

Penumpukan pada metode 1 dan 3 dilakukan dengan cetakan dan disusun secara berlapis. Lapisan paling atas dan paling bawah sedapat mungkin adalah sabut kelapa. Susunan lapisan pada metode ini yakni sabut-sayur-sabutsayur-sabut. Sedangkan pada metode 2 ditumpuk secara biasa menyerupai bentuk kerucut tanpa sistem lapisan, jadi bahan sayur dan sabut dicampur dari awal. Adapun gambaran tumpukan dapat dilihat pada Gambar 1.
5) Pembalikan dan penyiraman

Tujuan dari pembalikan adalah memberikan sirkulasi oksigen dalam tumpukan. Penyiraman dilakukan ketika tumpukan kompos terlihat kering atau melihat data kadar airnya telah berada di bawah $40 \%$.

6) Pemantauan parameter

Pemantauan parameter meliputi kadar air (3 hari sekali), $\mathrm{pH}$ (3 hari sekali), suhu (setiap hari), C-organik (akhir pengomposan), $\mathrm{N}$ total (akhir pengomposan) dan rasio $\mathrm{C} / \mathrm{N}$.

7) Pemanenan dan pengayakan

Pemanenan dilakukan dengan cara kompos diayak dengan mesin ayakan silinder. Pemanenan dilakukan ketika kompos telah menunjukkan ciri-ciri kematangan menurut SNI 197030-2004.

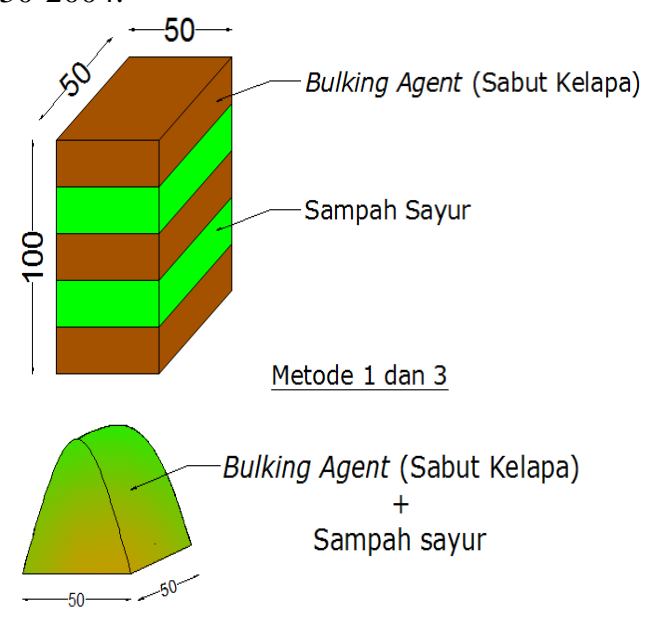

Metode 2

Gambar 1 Tumpukan untuk Ketiga Metode

D. Metode Pengumpulan Data

Metode pengumpulan data dalam penelitian ini sebagaimana tercantum dalam Tabel 2;

Table 2.

Metode Pengumpulan Data

\begin{tabular}{|c|c|c|c|}
\hline No & Parameter & Metode & Sumber \\
\hline 1 & Kadar Air & Pemanasan dengan oven & {$[6]$} \\
\hline 2 & $\mathrm{pH}$ & Soil test & - \\
\hline 3 & Suhu & Termometrik & [7] \\
\hline 4 & $\begin{array}{l}\text { Kadar C } \\
\text { organik }\end{array}$ & Walkey and Black & [8] \\
\hline 5 & Kadar N total & Kjeldahl dan spektrofotometri & {$[6]$} \\
\hline 6 & Rasio C/N & Perbandingan & - \\
\hline
\end{tabular}

\section{ANALISIS DAN PEMBAHASAN}

\section{A. Bahan Pengomposan}

Bahan pengomposan yang dipakai dalam penelitian ini adalah sampah sayur dan sabut kelapa. Sampah sayur didapatkan dari Pasar Puspa Agro dan Pasar Sepanjang, sedangkan sabut kelapa didapatkan dari Puspa Agro saja. Adapun karakteristik sampah dari kedua pasar tersebut tidak sama pada saat pengambilan. Sampah sayur yang berasal dari Pasar Puspa Agro didominasi oleh sawi dan kubis sedangkan 
dari Pasar sepanjang didominasi oleh kangkung dan daun singkong. Bahan awal pengomposan untuk masing-masing tumpukan dan berat awal pengomposan dapat dilihat pada Tabel 3.

Table 3.

Bahan Pengomposan untuk Masing-masing Tumpukan

\begin{tabular}{|c|c|c|c|c|}
\hline \multirow{2}{*}{$\begin{array}{l}\text { Tumpukan } \\
\text { (P) }\end{array}$} & \multicolumn{2}{|c|}{$\begin{array}{c}\text { Bahan Pengomposan } \\
(\mathrm{Kg})\end{array}$} & \multirow{2}{*}{$\begin{array}{l}\text { Jenis Sayur } \\
\text { dominan }\end{array}$} & \multirow{2}{*}{ Asal } \\
\hline & Sayur & $\begin{array}{l}\text { Sabut } \\
\text { kelapa }\end{array}$ & & \\
\hline P1 & 32,45 & 16,10 & sawi, selada & P. Puspa Agro \\
\hline P2 & 27,79 & 19,92 & sawi & P. Puspa Agro \\
\hline P3 & 21,72 & 23,89 & sawi, selada & P. Puspa Agro \\
\hline P11 & 37,19 & 15,93 & kubis & P. Puspa Agro \\
\hline $\mathrm{P} 22$ & 28,08 & 20,18 & sawi, kubis & P. Puspa Agro \\
\hline P33 & 22,10 & 24,21 & kubis, seledri & P. Puspa Agro \\
\hline $\mathrm{P} 4$ & 33,23 & 15,58 & kubis, selada & P. Puspa Agro \\
\hline P5 & 27,16 & 20,41 & sawi, kubis & P. Puspa Agro \\
\hline P6 & 21,50 & 23,49 & sawi, seledri & P. Puspa Agro \\
\hline P44 & 32,67 & 16,32 & kubis, bayam & P. Puspa Agro \\
\hline P55 & 22,43 & 19,82 & kangkung & P. Sepanjang \\
\hline P66 & 18,22 & 24,31 & $\begin{array}{c}\text { kangkung, } \\
\text { klobot jagung }\end{array}$ & P. Sepanjang \\
\hline P7 & 25,63 & 15,70 & $\begin{array}{l}\text { kangkung, } \\
\text { bawang prei }\end{array}$ & P. Sepanjang \\
\hline P8 & 21,34 & 20,15 & $\begin{array}{c}\text { kangkung, } \\
\text { daun singkong }\end{array}$ & P. Sepanjang \\
\hline P9 & 16,82 & 23,44 & $\begin{array}{c}\text { kangkung, } \\
\text { bayam }\end{array}$ & P. Sepanjang \\
\hline P77 & 34,21 & 15,90 & kubis & P. Puspa Agro \\
\hline P88 & 27,78 & 19,76 & sawi, brokoli & P. Puspa Agro \\
\hline P99 & 22,61 & 23,66 & kubis, sawi & P. Puspa Agro \\
\hline PK Tc & 55,41 & 0 & $\begin{array}{l}\text { sawi, kubis } \\
\text { daun }\end{array}$ & P. Puspa Agro \\
\hline PK C & 42,14 & 0 & $\begin{array}{l}\text { singkong, } \\
\text { kangkung }\end{array}$ & P. Sepanjang \\
\hline
\end{tabular}

Berat sayur dan sabut kelapa pada tabel di atas ditentukan berdasarkan perbandingan sesuai dengan variasi penambahan bulking agent. Perbedaan jenis sayuran dalam tumpukan kompos juga dapat mempengaruhi kondisi kompos. P1-P33 merupakan metode 1 (tidak dicacah, dilapis), dengan bulking agent $\mathrm{P} 1$ yaitu 40\%, P2 50\% dan P3 60\%. Sementara P11-P33 adalah duplonya. P4-P66 merupakan metode 2 (dicacah, dicampur) dan P7-P99 yakni metode 3 (dicacah, dilapis). Persentase penambahan bulking agent urutannya sama seperti pada metode 1. PKTc merupakan perlakuan kontrol tanpa dicacah, sedangkan PKC adalah kontrol yang dicacah.

\section{B. Perubahan Suhu}

Tumpukan kompos mengalami perubahan suhu yang berbeda antar metodenya. Namun, secara umum pada awal proses pengomposan, suhu meningkat hingga hari ke 2-5, dan selanjutnya suhu turun terus hingga stabil. Pada metode 1, sayur dan sabut yang tidak dicacah menyebabkan struktur yang kasar. Ukuran partikel dan struktur bahan kompos mempengaruhi sistem aerasi. Semakin kasar struktur bahan kompos, maka makin besar volume pori udara dalam tumpukan [9]. Sehingga panas yang dihasilkan dari proses degradasi bahan organik biodegradable akan mudah terlepas ke udara dan mengakibatkan suhu dalam tumpukan menjadi turun. Fluktuatif suhu dalam tumpukan pada metode 1 dapat dilihat pada Gambar 2. Suhu tertinggi dicapai oleh P11 yaitu $42^{\circ} \mathrm{C}$ pada hari kedua pengomposan. P11 mencapai suhu tertinggi karena bahan kompos lebih didominasi oleh kubis. Hal ini karena kubis mengandung air lebih dari $90 \%$, sehingga mudah mengalami pembusukan [10]. Oleh karena sifatnya yang mudah busuk, maka hasil dari respirasi mikroorganisme berupa energi dalam bentuk panas, $\mathrm{CO}_{2}$, dan air dengan cepat terbentuk. Pada hari ketiga dan seterusnya suhu mengalami penurunan dan menuju keadaan stabil. Hal ini menunjukkan bahan organik biodegradable terutama C-organik yang didekomposisi oleh bakteri semakin berkurang.

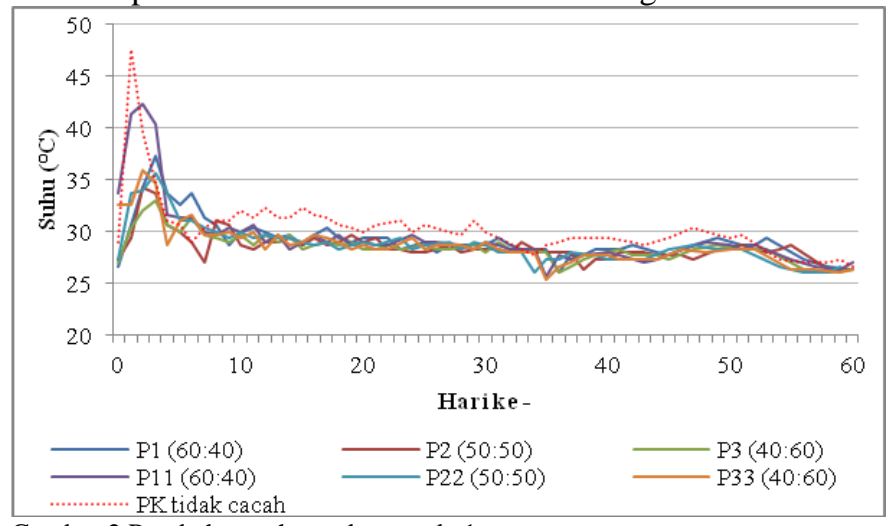

Gambar 2 Perubahan suhu pada metode 1

Pada metode 2, pencacahan yang dilakukan pada sayur dan sabut kelapa akan meningkatkan luas permukaan bahan kompos, sehingga memudahkan mikroba dekomposer untuk menghancurkan bahan kompos [9]. Sabut kelapa yang dicacah dapat menahan panas dalam tumpukan. Strukurnya yang makin halus dapat menutupi celah-celah pori dalam tumpukan. Peningkatan dan penurunan suhu tumpukan pada metode 2 dapat dilihat pada Gambar 3.

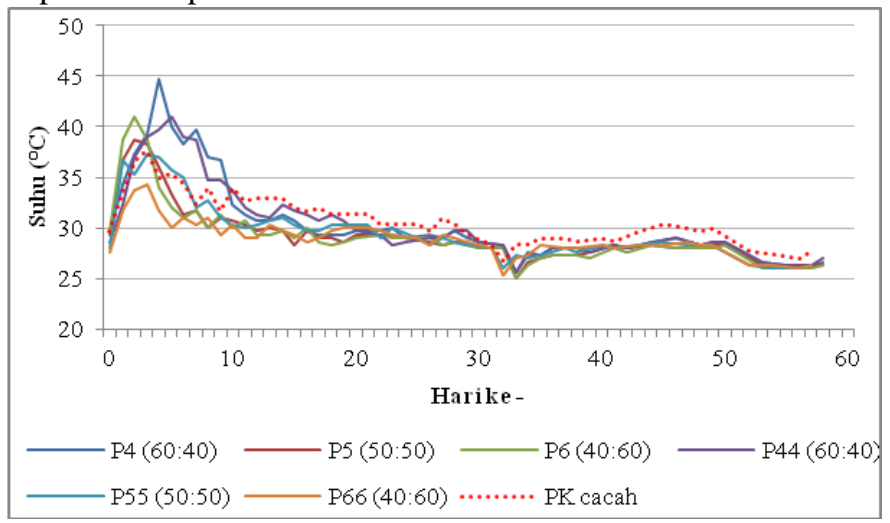

Gambar 3 Perubahan suhu pada metode 2

Pada Gambar 3, secara umum peningkatan suhu terjadi pada hari kedua hingga kelima. Waktu peningkatan suhu ini lebih panjang apabila dibandingkan dengan metode yang tidak dicacah. Hal ini karena bahan yang dicacah dapat dikonsumsi oleh mikroorganisme dengan lebih mudah, sehingga proses degradasi berlangsung dengan lancar. Oleh karena kemudahan dalam mendegradasi tersebut, suhu akan tetap tinggi seiring dengan proses degradasi yang menghasilkan panas.

Pada metode 3 kondisi tumpukan yang tinggi membuat panas yang dihasilkan dari proses degradasi akan tertahan oleh sabut dan sulit keluar. Tingginya suhu ini dapat menimbulkan 
asap yang keluar dari dalam tumpukan, dan ini terlihat pada hari ketiga ketika akan dilakukan pembalikan. Fluktuasi suhu pada metode 3 dapat dilihat pada Gambar 4. Suhu terendah dalam metode ini yaitu P9, dikarenakan jumlah sayurnya yang sedikit dibanding sabut kelapa. Sehingga hasil proses degradasi dalam bentuk panas akan sedikit juga.

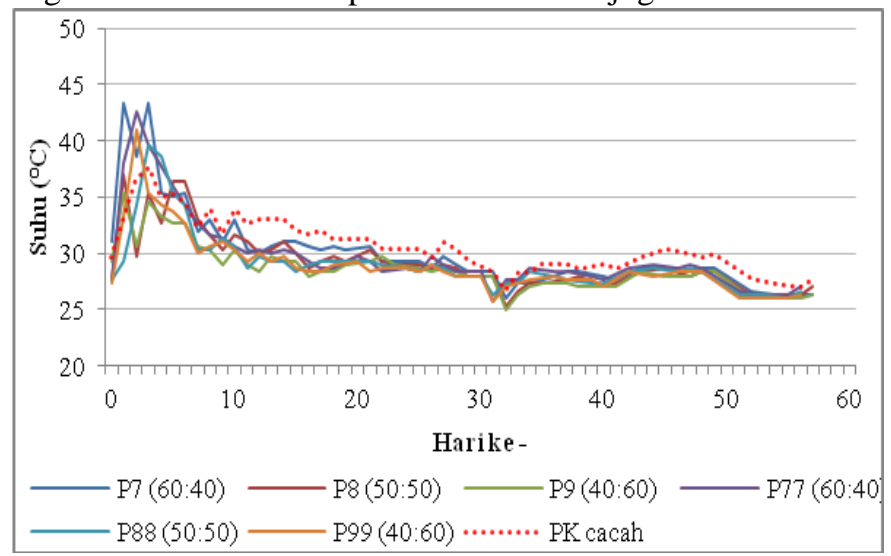

Gambar 4 Perubahan suhu pada metode 3

\section{Perubahan $\mathrm{pH}$}

Pengukuran $\mathrm{pH}$ dilakukan mulai pada hari ketiga pengomposan, hal ini dilakukan karena pada awal pengomposan sampah sayur dan sabut kelapa masih belum tercampur secara merata. Pada hari ketiga pengomposan, ratarata nilai $\mathrm{pH}$ untuk semua tumpukan yaitu $6,2-6,9$. Nilai $\mathrm{pH}$ yang rendah menunjukkan terjadinya pembentukan asam organik dari proses degradasi bahan organik [4]. Naiknya nilai $\mathrm{pH}$ disebabkan oleh penguraian protein menjadi ammonia $\left(\mathrm{NH}_{3}\right)$ yang berpengaruh terhadap peningkatan $\mathrm{pH}$ kompos [11].

Pada metode $1 \mathrm{pH}$ tumpukan pada hari ketiga dan keenam pengomposan adalah 6,6 hingga 6,9. Kenaikan $\mathrm{pH}$ terjadi pada hari keenam pengomposan yang mana hal ini menunjukkan terbentuknya $\mathrm{NH}_{3}$ dari proses pengomposan. Dan ini terbukti pada pembalikan hari keenam hingga hari kedua belas, aroma tumpukan lebih menyengat seperti bau amonia. Fluktuasi $\mathrm{pH}$ pada metode 1 dapat dilihat pada Gambar 5.

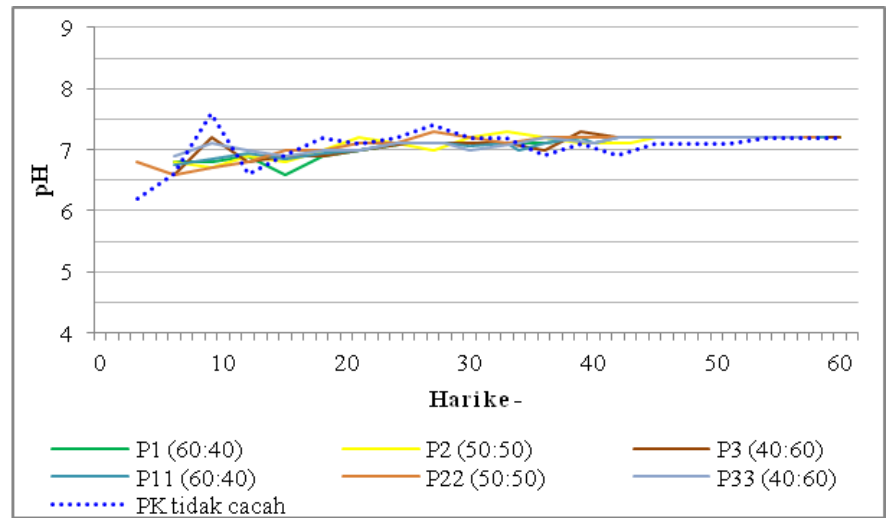

Gambar 5 Perubahan $\mathrm{pH}$ pada metode 1

Fluktuasi $\mathrm{pH}$ tumpukan pada metode 1 terjadi hingga hari kedua belas, sedangkan hari setelahnya $\mathrm{pH}$ cenderung netral. Perlakuan sayur yang tidak dicacah sedikit menghambat proses degradasi oleh bakteri sehingga kenaikan dan penurunan nilai $\mathrm{pH}$ tidak terjadi secara drastis.

Pada metode 2, adanya proses pencacahan menyebabkan penurunan $\mathrm{pH}$ berlangsung dalam jangka waktu yang lama yaitu hingga hari ke dua belas (Gambar 6).

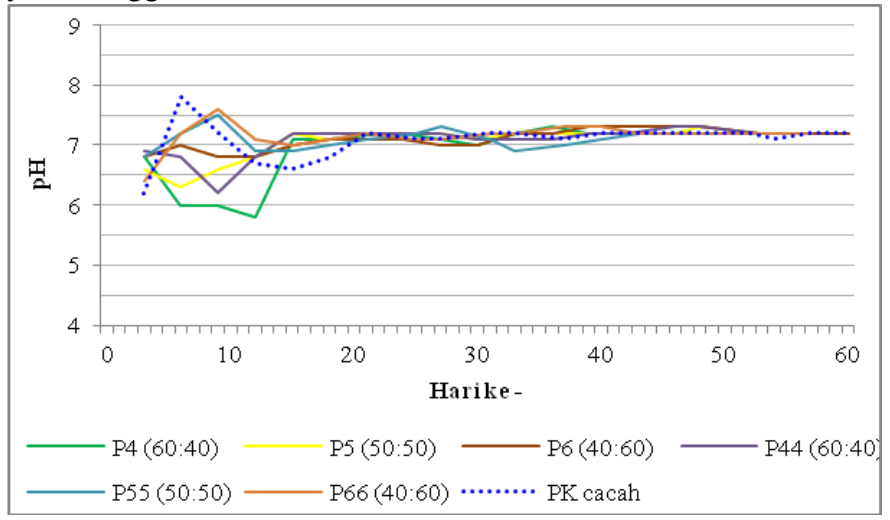

Gambar 6 Perubahan $\mathrm{pH}$ pada metode 2

Penurunan $\mathrm{pH}$ dalam jangka waktu yang lama ini terjadi karena sayur yang dicacah dapat dengan mudah didegradasi oleh bakteri. Sehingga proses pembentukan asam organik oleh bakteri berlangsung seiring dengan banyaknya bahan yang mudah didegradasi. Fluktuasi terjadi hingga hari kedua belas dan kelima belas waktu pengomposan, setelahnya $\mathrm{pH}$ kompos mendekati $\mathrm{pH}$ netral sampai proses pematangan.

Pada metode 3, dengan adanya peletakan bahan kompos yang berlapis mengakibatkan sayur tidak tersebar seperti pada metode 2. Hal ini dapat membuat pembentukan asam organik oleh bakteri tidak semudah apabila dibandingkan dengan kondisi tercampur. Hal tersebut karena proses degradasi bisa terhambat akibat adanya sekat antar sayur. Apabila dilihat secara rata-rata, fluktuasi $\mathrm{pH}$ pada metode ini diawali dengan peningkatan hingga hari keenam dan kedua belas, kemudian terjadi penurunan hingga mendekati $\mathrm{pH}$ netral pada hari setelahnya hingga waktu pengomposan selesai. Fluktuasi $\mathrm{pH}$ untuk metode 3 dapat dilihat pada Gambar 7.

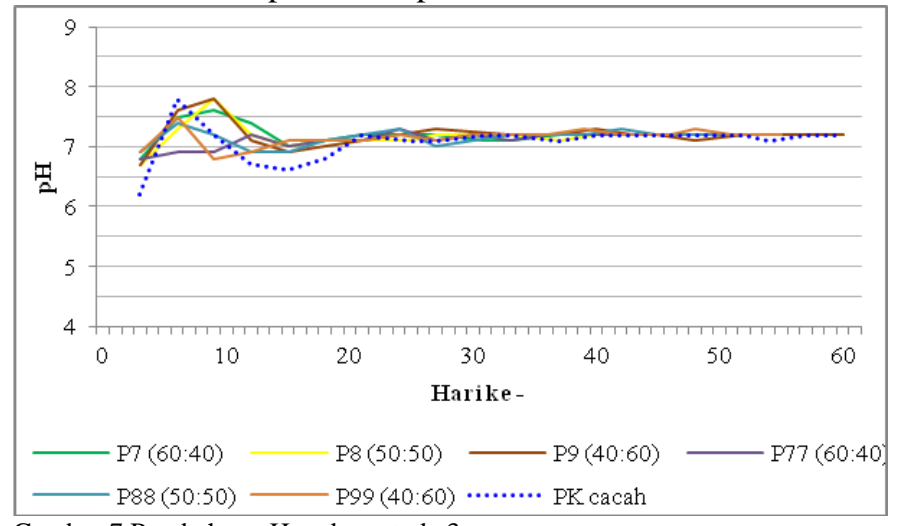

Gambar 7 Perubahan $\mathrm{pH}$ pada metode 3

\section{Perubahan Kadar Air}

Kadar air pada awal pengomposan berbeda untuk masingmasing tumpukan, hal ini diakibatkan oleh perbandingan sayur dengan sabut kelapa, jenis sayur yang mendominasi pada tumpukan dan metode pengomposan. Karena kadar air sayur lebih besar dari pada sabut kelapa yaitu 93\%. Selain itu sayur 
yang dicacah kandungan airnya lebih besar dari pada sayur yang tidak dicacah, karena pada sayur yang dicacah luas permukaannya semakin besar dan ukurannya kecil. Ukuran partikel yang semakin kecil, akan mempermudah bakteri melakukan degradasi dan akan menghasilkan cairan, sehingga kadar air akan meningkat [12].

Rujukan [13] menjelaskan kadar air 40-60 \% adalah kelembaban optimum untuk metabolisme mikroba. Apabila kelembaban di bawah $40 \%$, aktivitas mikroba akan mengalami penurunan. Penurunan ini menyebabkan kurangnya air untuk melarutkan bahan organik biodegradable yang akan didegradasi oleh mikroorganisme sebagai sumber energinya [12]. Maka dari itu, perlunya dilakukan penyiraman dalam tumpukan apabila kadar air dalam tumpukan telah di bawah $40 \%$.

Pada metode 1, kadar air di awal pengomposan berkisar antara 45-60\%. Kemudian pada hari keenam atau pada pembalikan kedua, kadar air pada semua tumpukan mengalami kenaikan hingga menjadi 55-62 \%. Hal ini mengindikasikan telah terjadi penguraian bahan organik biodegradable oleh mikroba di mana hasil dari proses tersebut berupa air. Air yang berlebih tidak mampu ditahan oleh sabut kelapa, sehingga air tersebut mengalir keluar tumpukan sebagai lindi. Peningkatan dan penurunan kadar air ini dapat dilihat pada grafik dalam Gambar 8.

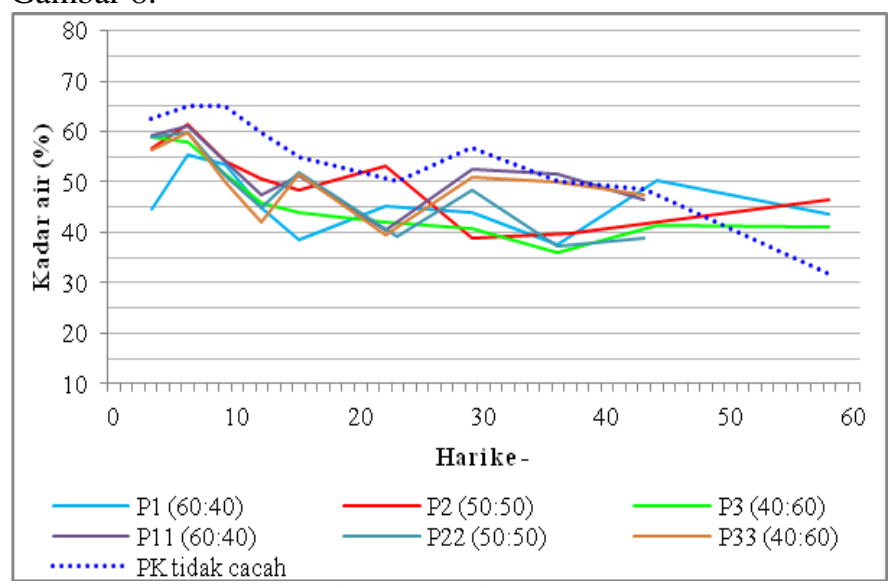

Gambar 8 Perubahan kadar air pada metode 1

Pada metode 2, sayur yang dicacah dapat meningkatkan kadar air dalam tumpukan pada fase awal. Karena semakin kecil ukuran bahan, maka air yang terkandung di dalamnya akan semakin banyak yang keluar. Perubahan kadar air dalam tumpukan pada metode 2 dapat dilihat pada Gambar 9.

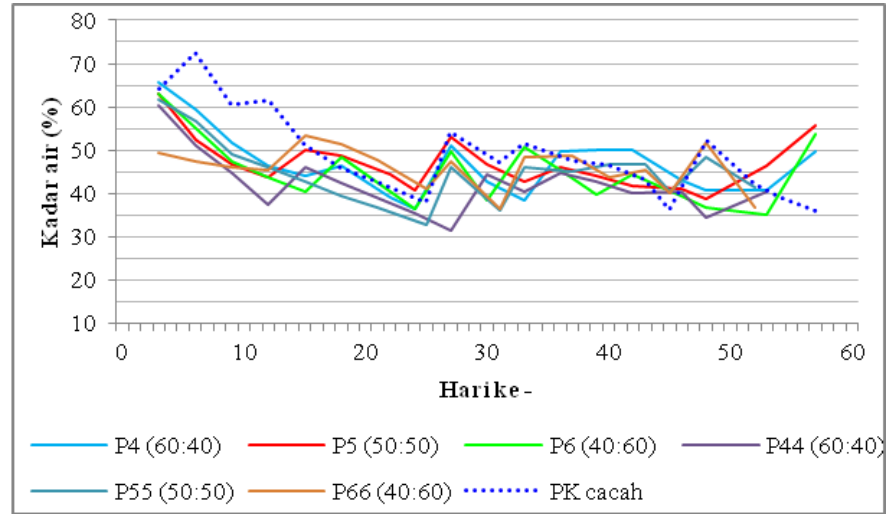

Gambar 9 Perubahan kadar air pada metode 2

Semua tumpukan dalam metode 2 mengalami penurunan kadar air hingga hari kedua belas waktu pengomposan. Hal ini disebabkan oleh bentuk tumpukan yang hanya ditumpuk biasa dan adanya pencampuran dari awal antara sayur dan sabut kelapa. Oleh karena tercampur, maka lapisan bawah dari tumpukan bukan merupakan sabut. Sehingga air yang mengalir dari dalam tumpukan tidak dapat ditahan dan akan keluar sebagai lindi. Pada hari kedua belas, dilakukan proses penyiraman untuk menghindari tumpukan terlalu kering, sehingga setelah hari tersebut kadar air kembali naik.

Pada metode 2, penyusunan bahan secara berlapis antara sayur dan sabut kelapa, maka air yang mengalir ke arah bawah tumpukan dapat sedikit tertahan oleh adanya sabut kelapa pada lapisan paling bawah. Sehingga kadar air dalam tumpukan dapat terjaga. Namun, analisis tersebut tidak terjadi pada tumpukan P7, P8 dan P9 (dapat dilihat pada Gambar 10).

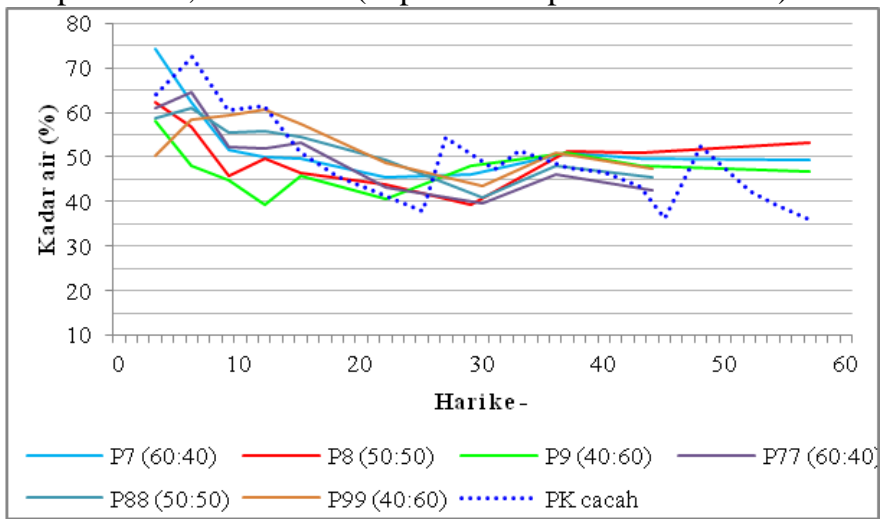

Gambar 10 Perubahan kadar air pada metode 3

Tumpukan P7, P8 dan P9 mengalami penurunan kadar air karena bahan dalam tumpukannya didominasi oleh kangkung. Sedangkan pada tumpukan P77, P88 dan P99 lebih didominasi oleh sayuran kubis dan sawi. Kadar air kangkung lebih rendah dari pada kubis, hal ini dibuktikan dalam penelitian [14]. Dengan kadar air yang sedikit, seiring berjalannya waktu, maka lama lama kadar air yang tedapat dalam tumpukan akan turun. Sedangkan pada tumpukan P77, P88 dan P99 yang bahannya memiliki kandungan air lebih tinggi, air yang keluar dan hasil dari proses degradasi (yang berupa air juga) tidak bisa secara langsung keluar tumpukan, akan tetapi tertahan dengan adanya lapisan sabut kelapa. Selain sifatnya yang 
mampu menahan air, sabut kelapa yang dicacah dapat mengurangi jumlah pori dalam tumpukan sehingga kemungkinan air untuk keluar dalam tumpukan akan berkurang.

\section{E. Perubahan Rasio $C / N$}

Proses degradasi dalam pengomposan membutuhkan Corganik untuk pemenuhan energi dan pertumbuhan, dan nitrogen untuk pemenuhan protein sebagai zat pembangun sel bakteri [15]. Hasil pengukuran $\mathrm{C}$ organik dan nitrogen total dalam penelitian ini menujukkan penurunan selama proses pengomposan. Perubahan rasio $\mathrm{C} / \mathrm{N}$ bahan pengomposan antara awal dan akhir dapat dilihat pada Tabel 4. Penurunan kandungan C-organik dalam tumpukan terjadi karena karbon digunakan oleh bakteri sebagai sumber energi untuk pertumbuhannya.

Pada metode 1 kandungan $\mathrm{C}$-organik lebih tinggi dari metode 2 dan 3, hal ini karena bahan yang tidak dicacah membuat mikroba kesulitan dalam mendegradasinya. Sehingga di akhir pengomposan C-organik yang tersisa juga lebih tinggi dari metode dengan pencacahan. Sedangkan pada pada metode 2 dan 3, bahan yang dicacah dapat membuat mikroba lebih mudah dalam mendegradasinya. Sehingga penurunan Corganik oleh mikroba lebih besar dari metode 1. Sedangkan kandungan $\mathrm{N}$ total yang besar ada pada metode 1, hal ini disebabkan sayur yang tidak dicacah akan membuat tingkat degradasi oleh mikroba lebih sulit. Sedangkan penurunan nitrogen total pada metode 2 dan 3 diakibatkan oleh hilangnya nitrat yang larut bersama lindi. Pada bahan yang dicacah, kandungan airnya lebih tinggi dari yang tidak dicacah, sehingga lindi yang dihasilkan lebih banyak.

Table 4.

Perubahan Rasio C/N dalam Pengomposan

\begin{tabular}{|c|c|c|c|c|c|c|}
\hline \multirow[b]{2}{*}{$\begin{array}{c}\text { Tumpukan } \\
\text { (P) }\end{array}$} & \multicolumn{3}{|c|}{ Awal } & \multicolumn{3}{|c|}{ Akhir } \\
\hline & $\begin{array}{c}\mathrm{C}- \\
\text { organik } \\
(\%)\end{array}$ & $\begin{array}{c}\mathrm{N} \\
\text { total } \\
(\%)\end{array}$ & $\begin{array}{c}\text { Rasio } \\
\mathrm{C} / \mathrm{N}\end{array}$ & $\begin{array}{c}\text { C- } \\
\text { organik } \\
(\%)\end{array}$ & $\begin{array}{c}\mathrm{N} \\
\text { total } \\
(\%)\end{array}$ & $\begin{array}{c}\text { Rasio } \\
\text { C/N }\end{array}$ \\
\hline P1 & 38,00 & 1,74 & 21,84 & 19,17 & 3,47 & 5,53 \\
\hline $\mathrm{P} 2$ & 38,87 & 1,55 & 25,16 & 21,03 & 3,38 & 6,21 \\
\hline P3 & 39,75 & 1,35 & 29,44 & 21,17 & 3,14 & 6,74 \\
\hline P11 & 38,00 & 1,74 & 21,84 & 18,35 & 3,58 & 5,12 \\
\hline $\mathrm{P} 22$ & 38,87 & 1,55 & 25,16 & 19,76 & 3,55 & 5,56 \\
\hline P33 & 39,75 & 1,35 & 29,44 & 24,62 & 3,35 & 7,34 \\
\hline $\mathrm{P} 4$ & 38,00 & 1,74 & 21,84 & 15,72 & 1,61 & 9,76 \\
\hline P5 & 38,87 & 1,55 & 25,16 & 16,78 & 1,49 & 11,29 \\
\hline P6 & 39,75 & 1,35 & 29,44 & 18,02 & 1,36 & 13,21 \\
\hline P44 & 38,00 & 1,74 & 21,84 & 15,87 & 1,70 & 9,35 \\
\hline P55 & 38,87 & 1,55 & 25,16 & 16,21 & 1,35 & 11,97 \\
\hline P66 & 39,75 & 1,35 & 29,44 & 17,65 & 1,34 & 13,21 \\
\hline $\mathrm{P} 7$ & 38,00 & 1,74 & 21,84 & 16,75 & 1,64 & 10,22 \\
\hline P8 & 38,87 & 1,55 & 25,16 & 18,88 & 1,59 & 11,88 \\
\hline P9 & 39,75 & 1,35 & 29,44 & 19,24 & 1,54 & 12,50 \\
\hline P77 & 38,00 & 1,74 & 21,84 & 16,96 & 1,79 & 9,47 \\
\hline P88 & 38,87 & 1,55 & 25,16 & 18,23 & 1,62 & 11,24 \\
\hline P99 & 39,75 & 1,35 & 29,44 & 18,69 & 1,59 & 11,79 \\
\hline PK Tc & 34,50 & 2,52 & 13,69 & 4,12 & 4,61 & 0,89 \\
\hline PK C & 34,50 & 2,52 & 13,69 & 3,53 & 3,48 & 1,01 \\
\hline
\end{tabular}

Rasio C/N pada metode 1 tidak ada yang mencapai rentang SNI (10-20). Sedangkan pada metode 2, hanya perbandingan 60:40 yang belum mencapainya. Pada metode 3 hampir semuanya masuk dalam kriteria SNI, hanya P77 yang tidak masuk rentang. Metode 3 (dicacah, dilapis) dalam hal ini menjadi yang terbaik apabila dilihat dari rasio $\mathrm{C} / \mathrm{N}$.

\section{F. Mass Balance}

Perubahan berat total yang menurun merupakan indikator kehilangan massa bahan organik biodegradable sebagai hasil respirasi [4]. Berat bahan yang hilang adalah gas-gas hasil penguraian oleh mikroba yang terbuang ke udara, misalnya amonia sehingga menyebabkan berat bahan akhir menjadi berkurang [14]. Selain itu hasil samping dari proses degradasi berupa $\mathrm{CO}_{2}$ dan air juga keluar dari tumpukan akibat penguapan atau menjadi lindi.

Metode yang mempunyai penurunan berat bahan yang besar adalah metode 2 (dicacah, dicampur) yaitu 78\% (berdasarkan berat kering). Hal ini karena metode ini dicacah dan dicampur ditumpuk biasa tanpa dicetak. Sehingga mikroba lebih mudah mendegradasinya karena tidak ada sekat atau lapisan sabut kelapa seperti pada metode 1 dan 3. Perubahan berat bahan pengomposan dalam penelitian ini dapat dilihat pada diagram mass balance pada Tabel 5. Sedangkan metode 3 (dicacah, dilapis) penurunan berat bahannya sebesar 49\%, hal ini lebih tinggi dari pada metode 1 (tidak diicacah, dilapis) yakni 33\%. Hal ini disebabkan karena meskipun sama-sama disusun secara berlapis, bahan yang dicacah dapat meningkatkan reduksi sampah.

Table 5.

Mass Balance

\begin{tabular}{cccc}
\hline \hline \multirow{2}{*}{$\begin{array}{c}\text { Tumpukan } \\
\text { (P) }\end{array}$} & \multicolumn{2}{c}{ Berat kering $(\mathrm{Kg})$} & $\begin{array}{c}\text { Persentase reduksi } \\
\text { total }(\%)\end{array}$ \\
\cline { 2 - 3 } & awal & akhir & \\
\hline P1 & 15,80 & 10,55 & 33,22 \\
P2 & 18,69 & 13,18 & 29,45 \\
P3 & 21,60 & 16,85 & 21,96 \\
P11 & 15,99 & 10,39 & 35,03 \\
P22 & 18,92 & 13,39 & 29,26 \\
P33 & 21,89 & 16,88 & 22,91 \\
P4 & 15,42 & 3,30 & 78,59 \\
P5 & 19,05 & 4,60 & 75,85 \\
P6 & 21,25 & 5,15 & 75,78 \\
P44 & 16,00 & 4,98 & 68,88 \\
P55 & 18,23 & 6,06 & 66,73 \\
P66 & 21,71 & 10,47 & 51,77 \\
P7 & 14,99 & 7,59 & 49,37 \\
P8 & 18,43 & 9,40 & 48,98 \\
P9 & 20,88 & 10,94 & 47,61 \\
P77 & 15,76 & 6,37 & 59,55 \\
P88 & 18,55 & 8,88 & 52,15 \\
P99 & 21,47 & 10,36 & 51,73 \\
PK Tc & 3,88 & 2,02 & 47,98 \\
PK C & 2,95 & 1,26 & 57,17 \\
\hline \hline
\end{tabular}

\section{G. Kualitas Kompos Matang}

Pemanenan kompos dilakukan pada waktu umur pengomposan 60 hari. Hal ini dilakukan karena ciri-ciri kematangan kompos telah terlihat yaitu warna coklat kehitaman, bau seperti tanah, suhu dan $\mathrm{pH}$ juga sudah stabil. 
Adapun kualitas kompos yang dihasilkan dalam penelitian ini dapat dilihat pada Tabel 6 .

\begin{tabular}{ccccccc}
\multicolumn{7}{c}{ Table 6 } \\
\multicolumn{7}{c}{ Kualitas Kompos Matang } \\
\hline \hline $\begin{array}{c}\text { Tumpukan } \\
\text { (P) }\end{array}$ & $\begin{array}{c}\text { Karbon } \\
(\%)\end{array}$ & $\begin{array}{c}\text { Nitrogen } \\
(\%)\end{array}$ & $\begin{array}{c}\text { Rasio } \\
\text { C/N }\end{array}$ & $\begin{array}{c}\text { Kadar } \\
\text { Air } \\
(\%)\end{array}$ & $\begin{array}{c}\text { suhu } \\
\left({ }^{\circ} \mathrm{C}\right)\end{array}$ & $\mathrm{pH}$ \\
\hline SNI 19- & $9,8-32$ & 0,4 & $10-20$ & $\begin{array}{c}\text { maks } \\
\text { 7030-2004 }\end{array}$ & maks & 6,8 \\
\hline P1 & 19,17 & 3,47 & 5,53 & 27,87 & 26 & 7,2 \\
P2 & 21,03 & 3,38 & 6,21 & 38,36 & 26 & 7,2 \\
P3 & 21,17 & 3,14 & 6,74 & 29,57 & 26 & 7,2 \\
P11 & 18,35 & 3,58 & 5,12 & 29,82 & 27 & 7,2 \\
P22 & 19,76 & 3,55 & 5,56 & 25,29 & 26 & 7,2 \\
P33 & 24,62 & 3,35 & 7,34 & 41,18 & 26 & 7,2 \\
P4 & 15,72 & 1,61 & 9,76 & 45,77 & 26 & 7,2 \\
P5 & 16,78 & 1,49 & 11,29 & 54,06 & 26 & 7,2 \\
P6 & 18,02 & 1,36 & 13,21 & 51,79 & 26 & 7,2 \\
P44 & 15,87 & 1,70 & 9,35 & 40,89 & 26 & 7,2 \\
P55 & 16,21 & 1,35 & 11,97 & 52,73 & 26 & 7,2 \\
P66 & 17,65 & 1,34 & 13,21 & 46,57 & 26 & 7,2 \\
P7 & 16,75 & 1,64 & 10,22 & 46,05 & 26 & 7,2 \\
P8 & 18,88 & 1,59 & 11,88 & 54,23 & 26 & 7,2 \\
P9 & 19,24 & 1,54 & 12,50 & 43,84 & 26 & 7,2 \\
P77 & 16,96 & 1,79 & 9,47 & 49,38 & 26 & 7,2 \\
P88 & 18,23 & 1,62 & 11,24 & 40,74 & 26 & 7,2 \\
P99 & 18,69 & 1,59 & 11,79 & 37,10 & 26 & 7,2 \\
PK Tc & 4,12 & 4,61 & 0,89 & 12,80 & 27 & 7,2 \\
PK C & 3,53 & 3,48 & 1,01 & 29,95 & 27 & 7,2 \\
\hline \hline
\end{tabular}

Apabila ditinjau dari variasi penambahan bulking agent, kualitas kompos yang dihasilkan dengan penambahan $60 \%$ lebih baik dari persentase yang lain. Namun jika ditinjau dari metode pengomposannya, baik penambahan 40\%, 50\% maupun $60 \%$ yang paling baik adalah pada metode 3 (dicacah, dilapis). Di antara penambahan tersebut, penambahan bulking agent $50 \%$ adalah yang paling baik dikarenakan rasio C/Nnya yang mendekati rasio $\mathrm{C} / \mathrm{N}$ tanah (10-12).

\section{H. Hasil Analisis Data dengan Uji Anova}

Analisis data dengan anova dilakukan untuk menguji adakah perbedaan rata-rata dalam kandungan C-organik, $\mathrm{N}$ total dan rasio $\mathrm{C} / \mathrm{N}$ terhadap jumlah bulking agent yang ditambahkan dan metode pengomposan. Angka significance level (taraf signifikansi) yang dipakai dalam uji ini yaitu 0,05 . Apabila nilai signifikansi di atas 0,05, maka dapat dikatakan tidak ada perbedaan rata-rata pada nilai parameter (C-organik, $\mathrm{N}$ total dan rasio $\mathrm{C} / \mathrm{N}$ ) terhadap variabel bebasnya. Namun apabila nilainya di bawah 0,05 , maka ada perbedaan rata-rata parameter terhadap variabel bebasnya. Sehingga apabila kejadiannya seperti itu, perlu diuji lanjut untuk mengetahui variabel mana saja yang berbeda.

Dari hasil uji anova antara parameter dengan jumlah penambahan bulking agent pada Tabel 7, nilai signifikansi semuanya di atas 0,05 , maka dapat dikatakan tidak ada perbedaan yang bermakna dari rata-rata parameter terhadap jumlah penambahan bulking agent.

Apabila dilihat dari hasil uji parameter dengan metode pengomposan pada Tabel 8, didapatkan nilai signifikansi di bawah 0,05, maka dapat dikatakan bahwa parameter Corganik, $\mathrm{N}$ total dan rasio $\mathrm{C} / \mathrm{N}$ menunjukkan perbedaan nilai rata-rat yang bermakna terhadap metode pengomposan. Untuk melihat metode pengomposan mana saja yang berbeda rataratanya, maka dilakukan uji lanjut yaitu uji Bonferroni. Uji Bonferroni ini dilakukan karena hasil uji kehomogenan varian mempunyai nilai signifikansi di atas 0,05 . Berdasarkan uji Bonferroni (Tabel 9), didapatkan bahwa metode pengomposan yang menunjukkan perbedaan rata-rata parameter (ada tanda *) adalah metode 1 dengan 2, dan metode 1 dengan 3. Sedangkan metode 2 dengan 3 tidak menunjukkan perbedaan rata-rata yang bermakna.

Table 7

Uji Anova Parameter Terhadap Penambahan Bulking Agent

\begin{tabular}{ccccccc}
\hline \hline & & $\begin{array}{c}\text { Sum of } \\
\text { Squares }\end{array}$ & df & $\begin{array}{c}\text { Mean } \\
\text { Square }\end{array}$ & F & Sig. \\
\hline \multirow{5}{*}{ C_organik } & Between Groups & 22.886 & 2 & 11.443 & 2.852 & .089 \\
& Within Groups & 60.193 & 15 & 4.013 & & \\
& Total & 83.078 & 17 & & & \\
N_total & Between Groups & .181 & 2 & .090 & .097 & .908 \\
& Within Groups & 14.011 & 15 & .934 & & \\
& Total & 14.192 & 17 & & & \\
Rasio_CN & Between Groups & 22.281 & 2 & 11.140 & 1.395 & .278 \\
& Within Groups & 119.777 & 15 & 7.985 & & \\
\hline \hline & Total & 142.058 & 17 & & & \\
\hline \hline
\end{tabular}

Uji Anova Parameter Terhadap Metode Pengomposan

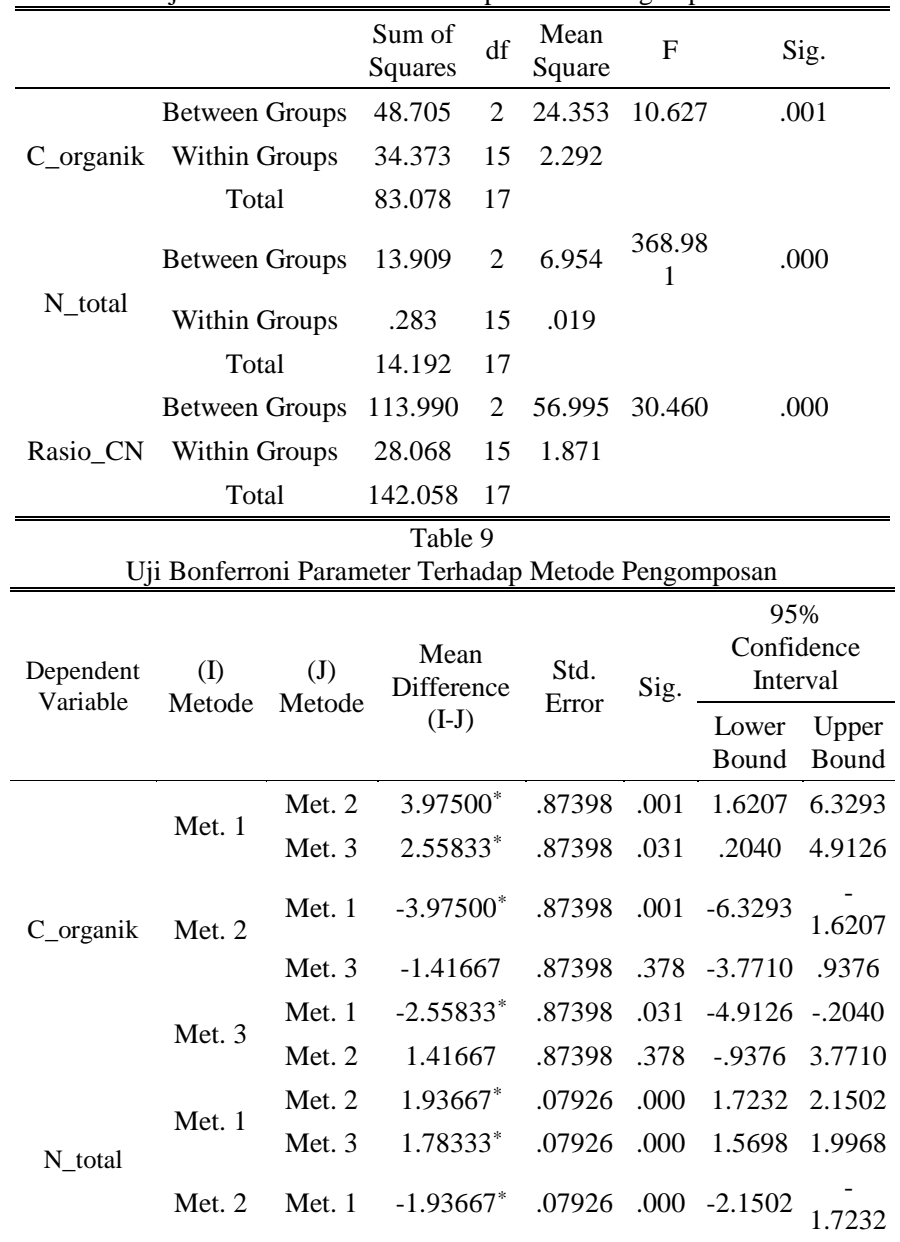




\begin{tabular}{|c|c|c|c|c|c|c|c|}
\hline \multirow{5}{*}{$\begin{array}{c}\text { Dependent } \\
\text { Variable }\end{array}$} & \multirow{2}{*}{$\begin{array}{c}\text { (I) } \\
\text { Metode }\end{array}$} & \multirow{2}{*}{$\begin{array}{c}(\mathrm{J}) \\
\text { Metode }\end{array}$} & \multirow{2}{*}{$\begin{array}{c}\text { Mean } \\
\text { Difference } \\
\text { (I-J) }\end{array}$} & \multirow{2}{*}{$\begin{array}{l}\text { Std. } \\
\text { Error }\end{array}$} & \multirow[t]{2}{*}{ Sig. } & \multicolumn{2}{|c|}{$\begin{array}{c}95 \% \\
\text { Confidence } \\
\text { Interval }\end{array}$} \\
\hline & & & & & & $\begin{array}{l}\text { Lower } \\
\text { Bound }\end{array}$ & $\begin{array}{l}\text { Upper } \\
\text { Bound }\end{array}$ \\
\hline & & Met. 3 & -.15333 & .07926 & .216 & -.3668 & .0602 \\
\hline & Met. 3 & Met. 1 & $-1.78333^{*}$ & .07926 & .000 & -1.9968 & $\begin{array}{c}- \\
1.5698\end{array}$ \\
\hline & & Met. 2 & .15333 & .07926 & .216 & -.0602 & .3668 \\
\hline \multirow{6}{*}{ Rasio_CN } & \multirow{2}{*}{ Met. 1} & Met. 2 & $-5.54833^{*}$ & .78976 & .000 & -7.6757 & $\begin{array}{c}- \\
3.4209\end{array}$ \\
\hline & & Met. 3 & $-5.10000^{*}$ & .78976 & .000 & -7.2274 & $\begin{array}{c}- \\
2.9726\end{array}$ \\
\hline & \multirow{2}{*}{ Met. 2} & Met. 1 & $5.54833^{*}$ & .78976 & .000 & 3.4209 & 7.6757 \\
\hline & & Met. 3 & .44833 & .78976 & 1.000 & -1.6791 & 2.5757 \\
\hline & \multirow{2}{*}{ Met. 3} & Met. 1 & $5.10000^{*}$ & .78976 & .000 & 2.9726 & 7.2274 \\
\hline & & Met. 2 & -.44833 & .78976 & 1.000 & -2.5757 & 1.6791 \\
\hline
\end{tabular}

\section{KESIMPULAN DAN SARAN}

Kesimpulan dari penelitian adalah apabila ditinjau dari variasi penambahan bulking agent, kualitas kompos yang paling baik yaitu dengan penambahan $60 \%$. Hasil yang diperoleh adalah suhu $26^{\circ} \mathrm{C}, \mathrm{pH} 7,2$, kadar air $46,57 \%$, Corganik $17,65 \%, \mathrm{~N}$ total $1,34 \%$ dan rasio $\mathrm{C} / \mathrm{N} 13,21$. Sedangkan ditinjau dari metode pengomposan, kualitas kompos yang paling baik yaitu menggunakan metode 3 (dicacah, dilapis). Hasil yang diperoleh yakni suhu $26^{\circ} \mathrm{C}, \mathrm{pH}$ 7,2, kadar air $40,74 \%$, C-organik $18,23 \%, \mathrm{~N}$ total $1,62 \%$ dan rasio $\mathrm{C} / \mathrm{N} 11,24$. Namun, ditinjau dari reduksi totalnya, metode 2 (dicacah, dicampur) yang paling besar dengan nilai mencapai $78,59 \%$.

Saran yang dapat diberikan dalam penelitian ini adalah perlunya diukur parameter lain seperti kalium, phospor dan kemampuan ikat air untuk membandingkan lebih jauh lagi kualitas kompos yang dihasilkan dari variasi penelitian. Selain itu bahan pengomposan untuk semua tumpukan diusahakan seragam agar perbandingan kualitasnya bisa valid antar variasi. Pengukuran parameter $\mathrm{C}$ dan $\mathrm{N}$ sebaiknya dilakukan dengan periode 5 hari-an atau per minggu agar dapat melihat laju penurunannya.

\section{DAFTAR PUSTAKA}

[1] Dinas Kebersihan dan Pertamanan Kabupaten Sidoarjo, "Timbulan dan Komponen Sampah Kabupaten Sidoarjo”, (2013).

[2] R. Sudradjat, Mengelola Sampah Kota. Bogor: Penebar Swadaya (2006) 7.

[3] B. Subali, Ellianawati, "Pengaruh waktu pengomposan terhadap rasio unsur $\mathrm{C} / \mathrm{N}$ dan jumlah kadar air dalam kompos," presented at the Prosiding Pertemuan Ilmiah XXIV HFI Jateng dan DIY, Semarang, (2010).

[4] J. Nugroho, N.S. Bintoro, T. Nurkayanti, "Pengaruh variaisi jumlah dan jenis bulking agent pada pengomposan limbah organik sayuran dengan komposter mini," presented at the Prosiding Nasional Perteta, Purwokerto, (2010).

[5] L. Murbando, Membuat Kompos. Jakarta: Penebar Swadaya (2008) 11.

[6] Apha, Awwa, Wpcf, Standard Methods for The Examination of Water and Wastewater. American Public Health Association/American Water
Works Association/Water Environment Federation, Washington DC, USA (2005).

[7] R. Rynk, M.v.D. Kamp, G.B. Wilson, M.E. Singley, T.L. Richard, J.J. Kolega, F.R. Gouin, L.L Jr, D. Kay, D.W. Murphy, H.A.J. Hoitink, W.F. Brinton, On-Farm Composting Handbook. Ithaca, NY: Northeast Regional Agricultural Engineering Service (1992).

[8] Soil Survey Standard Test Method Organic Carbon, Department of Sustainable Natural Resources, New South Wales, Australia.

[9] R.D.M. Simanungkalit, D.A. Suriadikarta, R. Saraswati, D. Setyorini, W. Hartatik, Pupuk Organik dan Pupuk Hayati. Bogor: Balai Besar Penelitian dan Pengembangan Sumberdaya Lahan Pertanian (2006).

[10] B.N. Widarti, W.K. Wardhini, E. Sarwono, "Pengaruh rasio C/N bahan baku pada pembuatan kompos dari kubis dan kulit pisang," Jurnal Integrasi Proses, Vol. 5, No. 2 (2015) 75-80.

[11] A.A.N. Supadma, D.M. Arthagama, "Uji formulasi kualitas pupuk kompos yang bersumber dari sampah organik dengan penambahan limbah ternak ayam, sapi, babi dan tanaman pahitan," Bumi Lestari, Vol. 8, No. 2 (2008) 113-121.

[12] E.S. Pandebesie, D. Rayuanti, "Pengaruh penambahan sekam pada proses pengomposan sampah domestik," Jurnal Lingkungan Tropis, Vol. 6, No. 1 (2013) 31-40.

[13] Isroi, Pengomposan Limbah Kakao. Jember: Pelatihan TOT Budidaya Kopi dan Kakao (2007) 5.

[14] A.H. Permana, R.S. Hirasmawan, "Pembuatan kompos dari limbah padat organik yang tidak terpakai (limbah sayuran kangkung, kol dan kulit pisang)," (2009) 1-6.

[15] A. Ismayana, N.S. Indrasti, Suprihatin, A. Maddu, A. Fredy, "Faktor rasio $\mathrm{C} / \mathrm{N}$ awal dan laju aerasi pada proses co-composting bagasse dan blotong," Jurnal Teknologi Industri Pertanian, Vol. 22, No. 3 (2012) 173-179. 